\title{
Strawberry growers wavered over methyl iodide, feared public backlash
}

by Julie Guthman

Methyl iodide, once promoted as a suitable alternative to methyl bromide for soil fumigation in strawberry systems, was withdrawn from the market in 2012 after a contentious regulatory battle that revolved around its high toxicity. At the time of its withdrawal, Arysta LifeScience, the maker of the chemical, claimed that it was no longer economically viable. In this study, I investigated what made the chemical nonviable, with a specific focus on growers' nonadoption of it. Interviews with strawberry growers in the four top California strawberry-growing counties revealed that growers' decisions not to use it were primarily related to public disapproval, although the continued availability of methyl bromide and other fumigants played a contributing role by making adoption less urgent. The study results suggest that policies in place during the methyl bromide phaseout did not strongly encourage the development and extension of less toxic alternatives, which undermined the strawberry industry's position.

$\mathrm{I}$ n March 2012, after a decade seeking regulatory approval for the soil fumigant methyl iodide, Arysta LifeScience withdrew it from the United States and other markets. Methyl iodide, registered by Arysta under the brand name Midas, was designed to replace methyl bromide, a favored soil fumigant among strawberry growers in California, which was destined for phaseout in compliance with the international Montreal Protocol on Substances that Deplete the Ozone Layer.

Methyl iodide had been promoted as a suitable alternative to methyl bromide because it shares its soil disinfestation qualities but does not present as much harm to the upper atmosphere (Ohr et al. 1996). Many argued, however, that it was more acutely toxic to humans and environmentally degrading than methyl bromide. Pesticide Action Network of North America, for example, reported it to be a known neurotoxin and carcinogen, associated with suppression of thyroid hormone synthesis, respiratory illness and lung tumors, and a probable cause of miscarriages and birth defects (PANNA 2011). As a preplant fumigant, methyl iodide, like methyl bromide, posed a health risk to those in the immediate vicinity of an application: farmworkers, neighbors and fumigation workers themselves. Methyl iodide poses no known risk to consumers.

During and immediately after regulatory review for approved use in California, methyl iodide met considerable opposition from public health, environmental and farmworker advocacy groups, which organized several protests, 
public hearings and over 53,000 written comments opposing its registration. Registration is the process by which government agencies license pesticides for use. To register a pesticide in California, the responsible party must first obtain approval from the U.S. Environmental Protection Agency (EPA). Then the chemical must undergo a thorough scientific evaluation by California's Department of Pesticide Regulation (DPR) to ensure it is effective and will not harm the environment or human health when used according to directions (DPR 2011, 19).

When DPR registered methyl iodide against the advice of its own agency scientists and external review committee as well as the opposition of the advocacy organizations, many of the organizations filed a lawsuit against both DPR and Arysta for failing to abide by California environmental law. Just in advance of a court ruling on the lawsuit that hinted to be unfavorable to Arysta, the company voluntarily revoked its request for registration and announced its plans to suspend operations in the U.S. market, publicly stating that the chemical was no longer economically viable.

An understanding of what led to the withdrawal of methyl iodide holds many lessons for stakeholders and the general public. A convergence of factors caused its demise, including DPR's mishandling of the registration process, which activists were able to exploit both in the court of public opinion and in the lawsuit (Froines et al. 2013). Yet, Arysta would likely not have withdrawn from the lawsuit had widespread grower adoption of methyl iodide demonstrated the chemical's economic viability.

This study investigated what made the chemical nonviable, with a specific focus on the lack of grower adoption. It was part of a large social science study that is investigating how tighter regulations on soil fumigants are affecting grower practices and the strawberry industry. My project team conducted 74 semistructured interviews with growers in four major strawberry-growing counties (see sidebar). We thematically coded these interviews using the qualitative data software NVivo10. In addition, we spoke with 40 people closely tied to the strawberry industry about their perspectives on methyl iodide, including shippers, pest control advisers (PCAs), research and

\section{Interview methods}

G rower interviews were conducted with standard social science methods for qualitative research. The project team obtained grower names and contact information through county agricultural commissioners' offices, which collect data on all pesticide use applications and make that publicly available by state law. However, not all contact information was correct and one county (Santa Barbara) did not provide contact information in its report. Owing to these difficulties, as well as the difficulty in reaching many growers, growers were selected for participation by convenience sample, meaning that those who were willing and available to participate were selected. The sample skewed somewhat to large, more established growers but was otherwise stratified along a number of dimensions.

The sample included growers in the four major strawberry-growing counties, Monterey $(n=22)$, Santa Barbara $(n=9)$, Santa Cruz $(n=19)$ and Ventura $(n=24)$. Six growers interviewed had under 20 acres in production, eight had 21 to 50 acres in production, nine had 51 to 100 acres, 46 had over 100 acres in production and five did not report. Five growers had all organic operations, 31 had mixed conventional and organic operations, and the remaining were all conventional.

Interviews were semistructured and ranged in time from 5 minutes on the phone to 2 hours in an office. The vast majority were full interviews in which all questions were answered. Questions addressed a range of issues and practices around strawberry production, including fumigation, varietal choice, rotations, labor and marketing. In regard to methyl iodide, we asked growers whether they had ever considered using it, and why they had or had not. In accordance with a human subjects protocol approved by UC Santa Cruz's Institutional Review Board, growers were free to refuse to answer questions and were promised nondisclosure of personally identifying information.

extension agents, independent researchers and people in grower organizations. For the purposes of this article, I also drew on documents from the lawsuit since they provide important data about the assumptions and perspectives of Arysta LifeScience.

\section{Methyl bromide phaseout}

Methyl bromide has been widely used since the 1970 s as a broad-spectrum soil sterilizer in seed production and in several important California cash crops. The strawberry industry has been its largest beneficiary and has seen enormous increases in productivity owing to its use (Goodhue et al. 2005). Methyl bromide reliably eradicates several soil pathogens that attack the root system of strawberry plants and is also very effective in controlling weeds and nematodes. Annual applications of methyl bromide have allowed strawberry growers to plant on the same block year after year; bi-annual applications have allowed them to rotate with vegetable growers every other year in regions with a long strawberry season (notably Monterey and Santa Cruz counties). Soil disinfestation alternatives that compromise yields or increase costs are thus necessarily noncompetitive.

Based on methyl bromide's contribution to ozone depletion, in 1991 the Montreal Protocol mandated the phaseout of methyl bromide, and as a signatory to the convention, the United States agreed to stop producing and importing it by 2005. As the phaseout drew near, however, the United States began requesting that the parties to the Montreal Protocol grant critical use exemptions (CUEs) for agricultural operations in which (a) not using methyl bromide would result in a significant market disruption and (b) there were no technically and economically feasible, available alternatives or substitutes that were acceptable from the standpoint of the environment and public health (US EPA n.d.).

A series of economic studies bolstered the case for CUEs by predicting yield losses and an industry shakeout without the use of methyl bromide and by stating that a viable alternative to methyl bromide did not exist (Carter et al. 2005; Goodhue et al. 2005). After intense lobbying by the United States delegation, largely speaking on behalf of the California strawberry industry, the CUE 
was incorporated into the Protocol and approved by signatories (Gareau and DuPuis 2009). Thereafter, approved CUE stocks could be allocated to fumigation companies, which would provide methyl bromide to growers who were certified as approved users, based on particular field conditions or township caps on alternatives (US EPA 2004). During negotiations, the United States agreed to stop producing and importing methyl bromide by 2015. Owing to the CUEs, use of methyl bromide on strawberries declined only marginally during the early periods of the phaseout, while it declined precipitously and even to negligible amounts for other crops (Goodhue et al. 2005).

As the 2015 phaseout drew near, methyl bromide became increasingly difficult and costly to access. Many began to rely more heavily on other, still allowable fumigants: they increased the percentage of chloropicrin they used in combination with methyl bromide, or they switched to chloropicrin alone or in combination with 1,3-D (Telone).

Meanwhile, the industry was slow to develop and test nonchemical alternatives, and, as of this writing, none has proven to be as reliable and cost effective as methyl bromide on a commercial scale. According to some of our interviewees, the procrastination in developing alternatives was in part a consequence of the CUE process, which created doubt among at least some in the industry that methyl bromide would ever be phased out.

\section{Methyl iodide regulatory troubles}

Methyl iodide was developed by researchers at UC Riverside as a potential replacement for methyl bromide, and licensed by Arysta LifeScience under the brand name Midas. In 2002, Arysta moved to get methyl iodide approved for commercial use, first seeking registration with the pesticide surveillance system administered by DPR. By virtue of the California Environmental Quality Act (CEQA), all pesticide registrations are subject to thorough reviews and analyses of risks, and responsible agencies must prepare risk characterization documents.

Because potentially hazardous chemicals require federal approval first, DPR's staff did not begin the risk analysis process for methyl iodide until early 2005. It completed an initial first draft in 2009, and then distributed it to the

\section{More than 50 scientists, several of them Nobel laureates in chemistry, delivered a letter to EPA asking the agency to deny registration of methyl iodide's use as a soil fumigant.}

EPA and then DPR. Due to emerging controversy surrounding the chemical - for example, in September 2007 more than 50 scientists, several of them Nobel laureates in chemistry, delivered a letter to EPA asking the agency to deny registration of its use as a soil fumigant - in April 2006 the EPA denied registration. A month later, it reversed course, granting a 1-year registration that, in 2008, was extended without time limitations.

In California, there are state environmental laws that go above and beyond federal standards, and a stronger
Office of Environmental Health Hazard Assessment (OEHHA) and an independent review panel of eight, convened by DPR.

OEHHA and the DPR panel provided extensive comments on the draft document by the end of 2009. Both expressed skepticism about the chemical's safety and in their risk assessment reports concluded that the application of methyl iodide in field fumigation could result in significant health risks for workers and the general population (DPR 2010c; Lim and Nu-May 2010). Nevertheless, in April

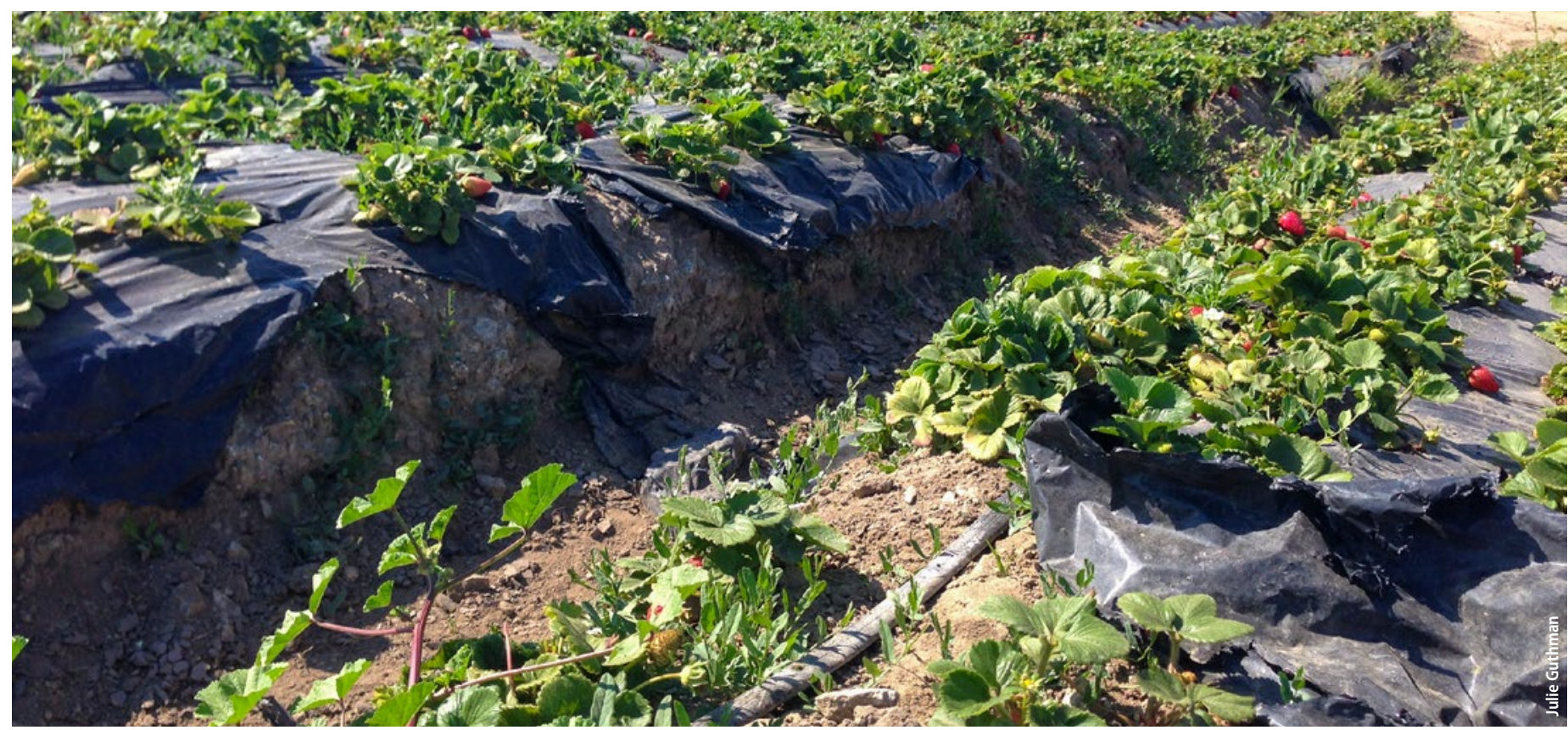

Methyl bromide has been used by growers since the 1970 s to control soil pathogens, weeds and nematodes. Above, weeds and pathogen wilt in a Santa Cruz County field that was not treated with methyl bromide. 
2010 Mary-Ann Warmerdam, DPR director at the time, announced her intent to register the chemical.

Warmerdam's announcement was a necessary step to kick off a CEQArequired public comment period. It was during this period that activist organizations, including environmental, public health and farmworker groups, mounted an internet campaign to encourage members of the general public to comment on methyl iodide registration. DPR received 53,000 comments, all but a handful objecting to the chemical's registration.

Despite this surge of opposition, and neglecting the recommendations of DPR's own staff and external review panels, Warmerdam approved methyl iodide for use as an emergency registration in December 2010, albeit with stricter mitigation measures than those required by the EPA label (DPR 2010a). In her statements, she acknowledged the volume of comments received but noted that she discounted them because "most of the comments received were similar and generated through social media campaigns" and "provided no evidence that DPR's stringent use restrictions [would] not keep exposures to methyl iodide within safe levels" (DPR 2010b).

Following approval, pressure mounted to reverse the decision. Owing to this pressure, the California Assembly's Environmental Safety and Toxic Materials and Health committees held several hearings in February 2011. In response to a petition filed a year prior by nearly a dozen advocacy organizations, a request by California Senator Diane Feinstein and a letter signed by thirty-seven California legislators, EPA agreed to open a 2-month public comment period in March 2011.

In late 2011, boards of supervisors in two major strawberry-producing counties, Monterey and Santa Cruz, passed resolutions requesting that the state of California withdraw approval of methyl iodide until additional research was completed, peer-reviewed and published. During 2011, activists organized many direct actions. Most visibly, they held mock fumigations on the steps of the state capitol and Arysta's offices (Greenaway 2011) and picketed some strawberry fields.

Meanwhile, activists had pursued legal action, filing a lawsuit on December 30, 2010, immediately following methyl iodide's registration.
The lawsuit was filed by Earthjustice, a nonprofit law firm, and California Rural Legal Assistance against DPR and director Warmerdam, and Arysta LifeScience, as the real party in interest (Pesticide Action Network of North America v. California Department of Pesticide Regulation (2010), Superior Court for the State of California, Alameda County). Most of the counts were about DPR's failure to abide by California environmental laws for transparency in decision making and its failure to make a robust assessment of potential health and environmental effects. The merits of the case were thus based on whether the agency had done due diligence in reviewing and evaluating all relevant material and whether it had made those reviews public. Helping the plaintiffs' case, the judge admitted a wide range of documents into evidence, including internal documents from DPR staff that controverted some of its public claims (interview with Greg Loarie, Earthjustice attorney, July 7, 2014).

The two issues that received the most attention during briefing and oral proceedings concerned adequate attention to the alternatives and the methodology for determining target concentration of the chemical. The plaintiffs contended that the DPR director had chosen to omit a range of scenarios in the final report. In addition, the final registration decision for methyl iodide sanctioned target concentrations of the chemical orders of magnitude higher than DPR staff scientists had recommended in their report. An internal memo DPR received from Arysta dated Feb. 16, 2010, revealed that Arysta had put pressure on DPR to come up with assumptions more favorable to Arysta. As narrated in oral arguments on Jan. 12, 2012, the memo stated:

There is still a gap between the current $D P R$ view and the scenarios that would lead to acceptable labels. It is also clear that this gap cannot be closed by label mitigation measures. It is essential to revisit the toxicology assessments to come up with less conservative assumptions.

Finally, the plaintiffs referred to a memo written by one of DPR's toxicologists to the director in which he questioned how the director had used a "mix and match" method to come up with a desired "acceptable" level of exposure.
The main hearing on the merits of the case, held on Jan. 12, 2012, showed that the court had grave concerns. The judge became impatient about the defendants' claim that they had explored alternatives, noting that the record did not include an environmental evaluation of the "no register alternative," required by the guidelines for registering a chemical. "I looked in vain in the record to try to find anything that actually was an analysis of the no project," the judge stated. When defendant's attorneys were unable to provide an adequate response, he said, "I have to tell you, [since] you had not done that [provided the evaluation of the no register alternative], this is a granted petition [plaintiffs win]. I just don't see how [given that] you didn't do that, you can say that you are CEQA compliant."

On Mar. 20, 2012, before the judge had ruled, Arysta requested that all parties appear in court the next day. At the beginning of that court session, before giving defendants a chance to speak, the judge informed the courtroom that he was preparing to rule against the defendants for violation of CEQA on the grounds that they had not adequately studied the alternatives. In addition he was intending to grant the plaintiff's petition for DPR to set aside its approval of methyl iodide because of lack of evidence that the director used a methodology that had scientific validity. Attorneys for Arysta then announced that Arysta was withdrawing its methyl iodide products from the U.S. market and had cancelled its registration with DPR that afternoon. The company had in fact issued a press release the previous day stating it was withdrawing Midas owing to methyl iodide's economic nonviability. The case was eventually declared moot, with the judge stating that the plaintiffs had received all the relief they could get.

\section{Economic troubles}

Arysta might have continued to pursue legal action had methyl iodide sales been robust. But, in fact, grower adoption of the chemical was minimal. As of December 2011, a year after registration, there had been only six permits issued in California, and, aside from field trials, the chemical had been applied to less than 20 acres, and Arysta had allegedly paid for those applications. All applications were less 
than 5 acres, and only one was on strawberries (Wozniacka 2012). According to one of the lawsuit documents, in the first quarter of 2012 there were no sales at all.

Table 1 summarizes growers' reasons for not using methyl iodide, based on coding of our interview data. (Due to time constraints and the open-ended nature of interviews, not all 74 growers interviewed responded to this question.) Of those who knew about the chemical $(n=46)$, a plurality did not adopt it out of concern for the bad publicity they would face from protestors and the public. "From what I understood, if you were gonna apply it, you would have protestors around your field," mentioned one grower. Many more simply noted that the public was against it.

Contributing to their concerns, several berry shippers did not want to be associated with a controversial chemical, having received word from retailers to whom they sold that they would not take the strawberries. These shippers had advised their growers not to use it. After relating that supermarket chains told one such shipper they would not carry berries from fields fumigated with methyl iodide, another interviewed grower said, "We couldn't adopt it because who would buy the berries if we used it?" The California Strawberry Commission, a grower marketing order, did not appear to support it either.

Some of the growers interviewed were disappointed in the methyl iodide outcome and angered by the protests, feeling that the activists had intentionally misinformed the public about its risk. "People thought we were spraying [it] and there were residues on the crop," reported one grower. These growers were responding

TABLE 1. Primary reasons for grower nonadoption of methyl iodide

\begin{tabular}{lcc}
\hline \hline Reason for nonadoption & $\begin{array}{c}\text { Number of } \\
\text { responses }\end{array}$ & $\begin{array}{c}\text { Percent of } \\
\text { responses* }\end{array}$ \\
\hline Concern with protestors, public backlash & 13 & $24 \%$ \\
Concern with toxicity of the chemical for themselves and workers & 9 & $17 \%$ \\
No opportunity to adopt & 10 & 7 \\
Not proven effective & 7 & $13 \%$ \\
Not interested, did not consider & 8 & $13 \%$ \\
No knowledge, or misunderstanding about chemical and controversy & 54 & $15 \%$ \\
Total & $700 \%$ \\
\hline
\end{tabular}

* Figures in this column do not sum to $100 \%$ due to rounding.

to the many public comments and news articles that falsely suggested that methyl iodide was a risk to consumers (as a preplant fumigant, the chemical's toxicity is generally limited to those who are in the vicinity of a fumigation). However, a surprising percentage of growers declined to adopt the chemical because they concurred with the activists that the chemical was excessively harmful, a sentiment that was shared by a couple of shippers. As put by one grower, methyl iodide was "pretty scary."

Another major reason growers did not adopt methyl iodide was that they did not have the opportunity to do so. Nineteen percent mentioned they would have tried it (or had conducted trials) but that either county restrictions or the uncertainty surrounding the chemical kept them from using it. "I didn't get a chance to really see a lot of it, because it seemed to be taken away so quickly," reported one grower. The window for trying the chemical was small; it was available for only 15 months, between when it was first registered on Dec. 29, 2010, and when it was taken off the market in March 2012, and there was a lawsuit pending the entire time.
Growers did not adopt the chemical also because they had not wanted or needed to. CUEs allowed methyl bromide to stay in the market, albeit in substantially lower amounts, and chloropicrin had proved reasonably efficacious, at least in the short term, so $13 \%$ of growers interviewed never seriously considered methyl iodide. "It is not worth it. I've got an alternative, which is chloropicrin ... it's not as good as methyl iodide, but I can't risk putting the reputation of our label in such an unfavorable light," said one grower.

Another 13\% were not sure of the chemical's efficacy.

Prior to registration, there had been very few field trials to demonstrate its efficacy, particularly at a commercial scale where buffer zones would come into play. While some growers had heard of good results, others were not swayed. As one said:

The trials that I saw with that [methyl iodide] didn't impress me... It's not so much what the environmentalists said. I went strictly on the research that was done and the comparison to the tools that we have now ... If it was something that, say, that worked better than methyl bromide, well, then it's a different story, but it wasn't working as effective (sic). 
With high land values, growers were understandably reluctant to take a risk on an unproven chemical. A final reason for nonadoption was that growers had never heard of the chemical.

These last three reasons - growers being uninterested in, unimpressed by or not knowledgeable about methyl iodide — representing $41 \%$ of those responding, suggest that extension for the chemical was unenthusiastic, if it existed. Most of the extension agents and PCAs with whom we spoke did not encourage its use, also in expectation of public pushback. It would have been rare, in any case, to have broad levels of adoption of a chemical that had barely been tested in its first year of release.

In the Blaser Declaration opposing the plaintiff's efforts to recoup attorney's fees (Blaser was the chief financial officer of Arysta), Arysta, in an effort to avoid paying those fees, revealed it had made many assumptions that proved unrealistic. The company did not expect the registration process to take a decade, and once the chemical was approved, the assumption was that it would immediately and fully replace methyl bromide. Arysta was not expecting DPR to impose buffer zones twice that of the EPA requirements, which significantly reduced the acreage to which a grower could apply it, while methyl bromide was not subject to such strict use restrictions. From Arysta's perspective, methyl bromide was competing with its replacement; "demand [for methyl iodide] had failed to materialize at all." In addition, too many unexpected costs were associated with methyl iodide, including the increased costs of regulations, and company operating costs of millions of dollars in the short term, with no prospects for significant change in the long term. Arysta tried to sell the methyl iodide license to three other businesses, but all backed out for the same reason of economic unsustainability that led Arysta to cancel the registration.

\section{Lessons learned}

Activism contributed to the failure of methyl iodide; it scared many shippers and growers into nonadoption and made extension agents and PCAs skeptical of introducing it. Regardless of whether the public understood that a preplant fumigant did not put consumers at risk, the activism was effective. Yet, it was not activism alone that made it economically nonviable. Arysta was too optimistic about the speed of the regulatory process and adoption. And yet, Arysta's assumptions might have been more reasonable had the strawberry industry not continued to obtain CUEs for methyl bromide long past the initial deadline for phaseout.

CUEs induced complacency in the industry, giving growers hope that the exemptions would persist and slowing down the development and testing of other alternatives, including less toxic alternatives. Not only did this complacency undermine the viability of methyl iodide, it put the industry in a weak position, with no scalable solutions for soil pathogens on the immediate horizon.

Given that obtaining CUEs effectively slowed the development of these very alternatives, the immediate lesson for growers and the strawberry industry is that technology-forcing regulation ought to be heeded rather than contested, especially given the time it takes to bring a new material to commercial viability. Moving forward, regulators and policymakers should consider policies that will jumpstart the development of alternatives and extend them widely. This is more urgent than ever. Since the methyl iodide campaign, other fumigants are facing more scrutiny and potential public pressure, and DPR has signaled its intent to phase out chemical fumigants altogether. For the industry, a favorable regulatory climate can no longer be assumed, and it needs to redouble its investment and experimentation in less toxic chemical or nonchemical alternatives. CA

\footnotetext{
J. Guthman is Professor of Social Sciences at the University of California, Santa Cruz.

This research was supported by the National Science Foundation (award \#1228478). As undergraduate research assistants, Madison Barbour, Yajaira Chavez and Savannah Coker were dutiful in transcribing and coding interviews. I am particularly grateful to Dr. Sandy Brown, who conducted many of these interviews and provided critical insights and observations. This report was improved by the comments of two anonymous reviewers and the journal's editors.
}

\section{References}

Carter CA, Chalfant JA, Goodhue RE, et al. 2005. The methyl bromide ban: Economic impacts on the California strawberry industry. Appl Econ Perspect Pol 27(2):181-97. doi:10.1111/j.1467-9353.2005.00220.x.

[DPR] Department of Pesticide Regulation. 2010a. About DPR's Decision to Register Methyl lodide. Sacramento, CA: State of California Department of Pesticide Regulation. www.cdpr.ca.gov/docs/registration/mei_pdfs/ mei_final_decision.pdf.

DPR. 2010b. Methyl lodide: Frequently Asked Questions. Sacramento, CA: State of California Department of Pesticide Regulation. www.cdpr.ca.gov/docs/registration/ mei_pdfs/mei_faqs.pdf.

DPR. 2010c. Report of the Scientific Review Committee on Methyl lodide to the Department of Pesticide Regulation. Sacramento, CA: State of California Department of Pesticide Regulation. www.cdpr.ca.gov/docs/risk/mei/ peer_review_report.pdf.

DPR. 2011. A Guide to Pesticide Regulation in California. Sacramento, CA: State of California Department of Pesticide Regulation. www.cdpr.ca.gov/docs/pressrls/ dprguide.htm.
Froines J, Kegley S, Malloy T, et al. 2013. Risk and Decision: Evaluating Pesticide Approval in California: Review of the Methyl lodide Registration Process. Los Angeles: Sustainable Technology and Policy Program, UCLA.

Gareau BJ, DuPuis EM. 2009. From public to private globa environmental governance: lessons from the Montreal Protocol's stalled methyl bromide phase-out. Environ Plann A 41(10):2305-23.

Goodhue RE, Fennimore SA, Ajwa HA. 2005. The economic importance of methyl bromide: Does the California strawberry industry qualify for a critical use exemption from the methyl bromide ban? Appl Econ Perspect Pol 27(2):198-211. doi:10.1111/j.14679353.2005.00221.x.

Greenaway T. 2011. Run and hide from methyl iodide. http://grist.org/scary-food/2011-08-29-methyl-iodidemock-fumigation/ (accessed Nov. 24, 2010).

Lim LO, Nu-May RR. 2010. Methyl lodide (lodomethane): Risk Characterization Document for Inhalation Exposure, Vol. 1, Health Risk Assessment. Sacramento, CA: State of California Department of Pesticide Regulation.
Ohr HD, Sims JJ, Grech NM, et al. 1996. Methyl iodide, an ozone-safe alternative to methyl bromide as a soil fumigant. Plant Dis 80(7):731-5

[PANNA] Pesticide Action Network North America. 2011. Methyl lodide. San Francisco: PANNA.

[US EPA] US Environmental Protection Agency. 2004. Protection of Stratospheric Ozone: Process of Exempting Critical Uses from the Phaseout of Methyl Bromide. Federal Register 69 (246)

US EPA. n.d. Critical Use Exemption Information. United States Environmental Protection Agency. www.epa.gov/ ods-phaseout/methyl-bromide. 